\title{
The Perceptions of the Psychological Counselors about Their Roles and Responsibilities Related to School Security
}

\author{
Adem Peker \\ Correspondence: Guidance and Psychological Counseling, College of Education, Atatürk University, Erzurum, Turkey
}

Received: July 21, 2015 Accepted: August 10, $2015 \quad$ Online Published: August 19, 2015

doi:10.11114/jets.v3i6.1043 URL: http://dx.doi.org/10.11114/jets.v3i6.1043

\begin{abstract}
The purpose of this study is to analyze the perceptions of the psychological counselors about their roles and responsibilities related to school security. The study group of the study is formed of 12 psychological counselors working in different school grades in Erzurum city center. The study is formed in qualitative design. Three themes as factors affecting school security, roles and responsibilities in terms of school security, the tasks that the psychological counselors can take in terms of school security have been created in the study. The data of the study was analyzed by using content analysis. As a result of the study, it is seen that the factors affecting the school security according to psychological counselors are physical and social environment of the school, school management and attitudes of the teachers, school security system. It is determined that the perceptions of the psychological counselors about their roles and responsibilities are psychological security, responsibility, legal acts and professional competence. It is also determined that the tasks that the psychological counselors can take are preventive studies and studies towards parents.
\end{abstract}

Keywords: school security, psychological counselor, role and responsibility

\section{Introduction}

Schools are complex human organizations where students, teachers, psychological counselors, social service specialists, nurses, school staff, families and other components of the society come together (Astor, Guerra \& Acker, 2010). The main purpose of the school is to train the students academically and prepare them for the life, and in this process train them in accordance with the basic values of the society (Buluç, 2006). Besides, schools play an important role in socialization of the students (Erol, 2009). It was seen that the children and the young who spend most of their time in school encounter such problems as dropping out, rejection by the peers, experiencing negative situations that damage mental and physical health. Such situations can be a risk factor for the school experience of the students. Thus, it has become a necessity to take security measures for the students to continue their education activities in a healthy environment. Baginsky (2004) stated that the main purpose of school security is to maintain a secure environment for both the teachers and the students, develop mental health of the students and motivate the personnel working in the school.

There are various definitions related to school security in the literature. Grene (2005) described school security as the process of developing school positively to create a strong commitment in the students and the parents towards the school. According to Reeves, Kanan and Plog (2010), a secure school is the school which prevents the occurring crises and decrease the negative effects, creates and maintains a positive school climate, applies good protection and interference programs. Bucher and Manning (2005) expressed that a secure school is a whole school climate in which students, teachers, managers, personnel and visitors are involved in positive interaction and which reflects the vision of the school, provides personal development, and attitudes and behaviors are made dominant. Posluoğlu (2014) stated that secure school is an institution in which students, teachers, all personnel and visitors approach in constructive behaviors, social life showing itself as the positive relations and civilized education require among the individuals.

* This study was presented as oral presentations in The International Congress on Education for the Future: Issues and Challenges ICEFIC 2015

Both the national and international studies have revealed the security problems experienced in the schools. Özer (2006) determined that students in state elementary school bring sharp objects like razor, razor blade, knives, and display aggressive behaviors more compared to those in private elementary schools. Geyin (2007) found in hiss study that the 
most important security problems in the schools are that the students carry dangerous tools like pocket knives and knives, robbery, students fights and threats. Güler (2010) determined that the most important security problems students have experienced in the recent year are verbal or physical attacks by elders or by individuals who are physically more powerful, robbery of valuable article or money, and the access of the ones who have nothing to do with the school to the school borders. Erol (2009) found in his study that the fact that the students, parents, teachers and managers consider classrooms and school buildings inadequate is an important factor in security problem in schools. In addition, it was revealed in the study that the inadequacy of playfield, playground and activity field, etc. cause security problem.

Klooster (2002) determined that 8,5\% of the students feel themselves insecure, approximately $14 \%$ of them fear certain areas of the school. Moreover, the study showed that almost $28 \%$ of the teachers cannot protect themselves from the violence and crime acts occurring in the school. Goldstein, Young and Boyd (2008) found that bringing guns to the school is related to being exposed to relational bullying, and student who are exposed to relational bullying at higher levels feel that the schools are less secure. Buffo (2005) determined that students, teachers and parents perceive that the school environment is insecure. Another result of the study shows that the higher rate of students from different ethnic origins causes the students to perceive the school insecure. Schneider, Walker and Sprague (2000) stated that strength, cleanliness, adequate lighting, adequate sport and social fields, emergency exits and security systems affect school security.

Schools are educational institutions where the individuals within the structure of them should feel themselves secure. It can be said that one of the things for an effective education is a secure school environment. In the changing world conditions, school security has become an important problem and it is possible that similar issues of this problem is experienced in our country. It is an undeniable fact that the necessity to conduct and increase the number of scientific studies related to school security for the methods to solve these problems (Çalıkoğlu, 2012). The security problems experienced in the schools can be described as the violence applied by the students to each other, the threats by the people outside the school, school gangs, bullying, drug use, robbery, security problems generating from the physical structure of the school, problems between students and teachers, etc.

The issues like violence, aggressiveness and situations experienced in schools, making the security of the schools vulnerable, are considered with a concern by both families, teachers and managers in the schools and authorities. Many methods have been applied to determine the factors causing school violence, to decrease and prevent school violence. Closed circuit security cameras, private security guards, card entry systems, metal detectors, hall monitors (both the students and the teachers) and lastly school police can be given as examples to the applied methods (Ayar, 2010). However, it's been observed that these applications are not sufficient. Policy makers have already started to conduct new studies for different applications related to school security.

In the $19^{\text {th }}$ National Education Council, a suggestion was made to reorganize the Guidance and Psychological Counseling Services Regulation to include the roles and responsibilities of the school counselors related to school security. It is though that determining the views of the school counselors whose roles and responsibilities are thought to be increased in planning both acts of violence among students and interventions towards violence would help form an opinion for the legal regulations that will be made for school security. It is also thought that with its contribution to the literature it will present a different point of view to the researchers for their studies related to this subject, and it will light the way of the policy makers and operators in planning measures to make schools more secure. In this direction, the perceptions of the psychological counselors working in different school grades about their roles and responsibilities related to school security will be analyzed within this study. The hypothesis related to the study are presented below.

1. What are the views of the psychological counselors related to the factors affecting school security?

1.1. What are their views related to the fact that the physical and social environment of the school affect school security?

1.2. What are their views related to the fact that the attitudes of the school management and the teachers affect the school security?

1.3. What are their views related to the fact that the school security system affects the school security?

2. What are the views of the psychological counselor related to their roles and responsibilities about the school security?

2.1. What are their views related to psychological security?

2.2. What are their views related to the legal regulations?

2.3. What are their views related to the responsibility?

2.4. What are their views related to professional competence? 
3. What are the views of the psychological counselors related to the tasks they can take about the school security?

3.1. What are their views related to the preventive studies?

3.2. What are their views related to the studies towards parents?

\section{Method}

\subsection{The Design of the Study}

Qualitative research pattern is used in this study to determine the roles and responsibilities of the psychological counselors. The main feature of qualitative research is that a fact, event, norm and values are analyzed through the perspectives of the ones on whom the study is conducted. It is an important study strategy to dwell on and try to understand the special language, meanings, terms that the individual being analyzed create and use during the research and to reveal what those mean for them (Ekiz, 2013).

\subsection{Participants}

The participants of the study are 12 psychological counselors working in different school grades in Erzurum city center. In the selection of the participants, it was considered that they should be working tenure in their current schools at least 2 years. 6 of the psychological counselors works secondary school, 4 of them in high school and 2 of them work in primary school. Professional seniority of the psychological counselors ranges between 2 and 12 years, their ages range between 23 and 34 .

\subsection{Data Collection Tools}

The data of the study is collected with semi-structured interview technique. In this technique, the researcher prepared the interview questions in advance. However, the prepared questions are allowed to be reorganized and discussed by providing partial flexibility to the participant during the interview. In such an interview, the control of the participants is also on the study (Ekiz, 2013). The semi-structured interview form was developed by the researcher. The researcher asked the opinions of 3 exerts who have at least Ph.D. degree in the field of guidance and psychological counseling, curriculum and educational administration in the development stage of the interview form. After taking the experts' opinions, corrections were done on the interview form. Thus, the interview form has taken its final shape. The interview form consists of questions related to the roles and responsibilities of the psychological counselors about the school security. Before asking the questions to the participants, explanations about the school security were done and then their views were received. The questions to be asked to the participants were structured as factors affecting the school security, studies conducted towards the students causing school security problems, roles and responsibilities about school security, tasks the psychological counselors can take. Recorder was used in the interviews. And, permissions were granted from the participants before starting the interview.

\subsection{Analysis of the Data}

Descriptive analysis was firstly done on the interview recordings of the psychological counselors. After the descriptive analysis, the data was analyzed by using content analysis. The main purpose of the content analysis is to reach terms and relations which can explain the obtained data. The data summarized and interpreted in the descriptive analysis are processed in a deeper way and terms and themes that cannot be distinguished with a descriptive approach are explored as a result of this analysis (Yıldırım and Şimşek, 2006). For this purpose, the obtained data was conceptualized and themes were determined according to these concepts. The data of the study were processed and described according to this theme. The descriptions were supported with direct quotations. Quotations were indicated with parenthetical coding. The first letter in the parenthesis indicates participant's name, the second one indicates school grade, the first number indicates age, the letter at the side of the number indicates gender, and the last number indicates professional seniority.

\section{Findings}

\subsection{Factors Affecting the School Security}

According to psychological counselors, the factors that affect the school security were determined in three categories as physical and social environment of the school, the attitudes of the school management and the teachers, and school security system.

\subsubsection{Physical and Social Environment of the School}

The views of the psychological counselors related to the physical and social environment of the school can be expressed as following: "All the schools should have the goods to carry out its social activities. Library, canteen, gym, internet, etc. lacking these in the schools casts away the students from the schools and dispatches them to the internet cafes and buffets whose security is a matter of everyday debate. Environmental conditions are important so the fields on which a 
school will be built should be safe. When the student gets out of the school, s/he can get home or school bus without being disturbed by anyone" [HHS, 28, M, 4]. "At the top of the factors that affect the security of the school comes the physical environment and the cultural structure of this environment. Particularly the school managers should know the structure of the society well" [MPS, 27, M, 4]. "I think that school security not only includes the times inside the school but also the periods in which the student goes to school from home. One of the problems we experience is that the driver of the school bus harass one of our school girls" [AHS, 25, F, 3]. "That the students encounter strangers on their way home or school makes them uncomfortable. Besides, we see people outside the school who wants to meet or talk to the school girls, lingering around the school. These people generally smoke and this is happening around the school and this endangers our students" [BÇHS, 24, F, 3].

\subsubsection{Attitude of the School Manager and the Teacher}

The views of the psychological counselor related to the attitudes of the school managers and the teachers are as follow: "Developing a common attitude with management and teachers affects the behaviors of the students, thus the school security" [BTPS, 23, F, 2]. "The attitude of unsuccessful and problematic students, not applying disciplinary rules (verbal warning, reprimand, etc.) Against negative behaviors and sometimes ignoring them, that some students do not obey the rules and consider them unnecessary, inadequacy of the activities related to the rehabilitation of the students, indifference of the families towards their problematic children, not teaching social values sufficiently to the students affect the security problem" [TMS, 29, F, 7]. "The drawback of the school management in applying the disciplinary regulations and applications affects the school security" [SMS, 32, M, 10]. "Intramural fights occurring because the school management does not act responsibly, and because the school is big, events occurring in the school are not interfered on the scene, all of which causes security problems" [AHS, 25, F, 3].

\subsubsection{School Security System}

The views of the psychological counselors related to the school security system are as follows: "I think one of the most important factors affecting the school security is that the security systems are not completely constituted. What affects this is that security staff in the school do not do their jobs properly and inspections are inadequate" [KHS, 25, M, 2]. "I believe that as there is no security guard in the school and teachers as hall monitors do not properly monitor the hall, the school security decreases" [BÇHS, 24, F, 3]. "If I'm to evaluate the last 5 months, the fact that there is not any security guards or officers in the school leaves the school unprotected against the possible attacks from outside the school. I consider drugs being leaked into the school creates the biggest problem. At this point, teachers remain incapable. As I work in girls' high school, it wouldn't be wrong to state that the school is invaded by unknown people who want to make contact with the school girls somehow" [HHS, 28, M, 4]. "The fact that so-called visitors who are strangers and can be dangerous can enter the school affects the school security" [KMSO, 30, M, 7]. "Entries and exits are not controlled in the schoolyard. The visitor, parents are not recorded, there are shortcomings related to informing about earthquakes, fire, civil defense and these causes inadequacy in terms of security" [SMS, 23, F, 2].

\subsection{Roles and Responsibilities}

The views of the psychological counselors related to their roles and responsibilities about school security are dealt in four basic categories. These categories are psychological security, responsibility, legal regulations and professional competence.

\subsubsection{Psychological Security}

The views of the psychological counselors related to psychological security are as follow: "Psychological counselors have a didactic, consciousness raising and raising awareness roles as s/he does preventing and interfering studies related to the problems like preventing violence particularly towards the students, peer victimization, bullying, abuse, neglect, drug abuse, health, nourishment, cleanliness, informing about contagious diseases. [SMS, 23, F, 2]. "Psychological counselors can train students about subjects like anger management, drug addiction and peer pressure. However, they cannot be regarded as responsible for the security problems caused by physical conditions" [AHS, 25, F, 3]. "Psychological counselors are like backbone of the school in terms of anger management, breathing exercises and communication" [BÇHS, 24, F, 3]. "The most important mission of the Counseling Service is to include more rehabilitative activities towards the problematic students" [KHS, 25, M, 2].

3.2.2 Legal Regulations

Psychological counselors want their roles and responsibilities to be made clear about the works related to school security. The views of the psychological counselors related to legal regulation are as follow: "As our job is an open-ended job, our roles and responsibilities should be made clear with regulations or else the school management would give us tasks which are irrelevant to our job. Almost all the school managers already consider us not working" [HHS, 28, M, 4]. "The current regulations are not sufficient. As our duties and responsibilities are not stated clearly, 
school managers think that the responsibility is ours to take. Everyone's duties and responsibilities should be made clear in the regulations and school managers should be trained about this subject" [KMS, 30, M, 7]. "The greatest absence related to school security and preventing violence is the absence of regulations" [MPS, 27, M, 4].

\subsubsection{Responsibility}

Psychological counselors stated that they are allocated with lots of responsibilities in the works related to school security, there is no equal distribution of the roles among school management, teachers and school personnel. The views of the teachers related to responsibility can be seen below: "All the responsibility is generally allocated to the school counselor related to the subjects like school security and violence" [AMS, 34, M, 12]. "Sharing the idea that we have considerably responsibility in the security problems which can be caused by the students in our school, I think that this is not only the school counselor's responsibility but also the responsibility of classroom teachers and school management. I don't think that we have the responsibility for the dangers originating from the outside of the school [BTPS, 23, F, 2]. "The problem of security is an all out problem. Thus, it cannot be accepted that it is allocated only to the counselor. Psychological counselors also carry on their works collaboratively. All the school personnel should be trained carefully [KHS, 25, M, 2].

\subsubsection{Professional Competence}

Psychological counselors stated that some of them consider themselves professionally competence in the works related to the school security, and some of them consider themselves incompetence. The views of the psychological counselors related to professional competence category are as follow: "There are times that I feel myself professionally incompetence. I try to create keys to the situation by exchanging views with my colleagues. To increase my professional competence, trainings containing not only theoretical contents but also practices would be beneficial" [AHS, 25, F, 3]. "From time to time, I remain incapable, increasing experience and education opportunities will also increase my competence" [BÇL, 24, F, 3]. "I don't consider myself competence in these subjects because this is a subject which requires specialty and we can only be able to be beneficial to other party through serious trainings. Trainings related to this subject can be more frequently given to the school counselors" [BTPS, 23, F, 2].

"I partially consider myself competence in terms of school security and preventive stuff but I believe that this is only possible if I gain more and more experience in my profession. I think that Counseling Service should be given more in-service trainings to increase especially school security in terms of professional competence. For example, I believe that a training titled with crisis management would be effective in responding properly to a student having problems at the first response and also in school security. Moreover, I don't approve that Counseling Service maintain school security by getting angry, yelling or beating because of my faith in my profession. At this point, I believe that functional ways to show what the proper responses are and those situations I've mentioned are wrong should be re-trained through a seminar or different studies" [KHS, 25, M, 2]. "I consider myself competence but I think that seminars and in-service trainings towards psychological counselors and teachers would increase the efficiency in this subject" [SMS, 23, F, 2].

\subsection{The Tasks the Psychological Counselors can Take Related to School Security}

The views of the psychological counselors related to the tasks they can take related to the school security is evaluated under two basic titles. These are preventive studies and studies towards parents.

\subsubsection{Preventive Studies}

The views of the psychological counselors related to preventive studies can be expressed as follow: "In terms of school security, we can take charge in the training of the students about the subjects like anger management, peer pressure and proper communication methods. Apart from this, we can work with the students who threaten the school security in terms of giving them psychological support" [AHS, 25, F, 3]. "Teamwork, individual interviews, informative seminars at school levels towards the students who can cause security problems in the school are possible” [BTPS, 23, F, 2]. "We can consider preventive studies as response to crisis. For instance, I gave seminars about safe internet using, drug addiction, technology addiction, healthy life, bad habits to my students. I invited medical personnel and police officers to the school. Also, I invited information technologies specialist to the school and we conducted studies together" [HHS, 28, M, 4]. "I believe that we have the some duties to solve school security issues, especially security problems caused by the students in the school. At this point, I believe that enjoyable and instructive activities (like dramas about the negative effect of anger on the body and emotions), giving the students to experience anger management, teaching them making proper response trainings should be popularized in the school by getting the support of the school management" [KHS, 25, M, 2]. "Each psychological counselor should implement violence action plan concertedly with the teachers in the school. In case of violence, bullying, aggressiveness in school, psycho-social interventions should be coordinately implemented. Empathy, expressing himself/herself, enterprise skills, social skill training, anger 
management, conflict resolution skills should be taught. Besides, psychological counselors should take a part in decreasing problematic behaviors by orienting the students who are temptation, tend to violence, aggressive behaviors, etc. to activities according to their interests and skills to maintain school security” [SMS, 23, F, 2].

\subsubsection{Studies towards Parents}

The views of the psychological counselors related to the studies towards parents are as follow: "Studies towards parents can be carried out. In this subject, parents can be given informative trainings. With this, parents can manage to take precautions to prevent the negative behaviors of the students" [AMS, 34, M, 12]. "Of course there are. Student behaviors (particularly those tending to violence) should be observed and these behaviors should be tried to be better by interviewing with the parents" [MMS, 24, F, 2]. "Parents should be informed about the risk factors" [SMS, 32, M, $10]$.

\section{Discussion}

The purpose of this study is to determine the perceptions of the psychological counselors about their roles and responsibilities related to school security. As a result of the study, the factors that affects the school security were collected under three different titles as physical and social environment of the school, attitude of school management and teachers and school security system. This result obtained from the study is parallel with the results of the studies in which it was determined that as the environmental security perceptions of the students increase, their hostile behaviors decrease (Nair, 2014); there is a relationship between the physical environment of the school and the behaviors of the problematic students (Kumar, O'Malley \& Johnston, 2008).

It is stated that the physical conditions of the schools do not have a standard for natural disasters and necessary external factors and thus this shortcoming creates serious security risks in the schools. Moreover, it is stated that because the tools and the toys are not designed for different age groups in the schoolyard and the playground, it can cause communication problems among different age groups (Posluoğlu, 2014).

According to the psychological counselors, one of the factors that affects school security is the attitude of the school management and the teacher. The school management can establish rules related to the school process to create a healthy education environment, to prevent students from damaging each other, their teachers and the equipments of the school. Sanctions such as reprimand, suspension or expelling can be implemented for the students who do not obey the rules in the school (Osher, George, Jeffrey \&Walter, 2010). Likewise, teachers can refer the students who disrupt the lesson, behave improperly to his/her friends and teachers to disciplinary committee. The disciplinary politics which is applied for the students getting educated in the school can be effective in solving the problems related to school security. At this point, the school managements can provide a secure environment to the students by keeping the rules implemented fairly and on time.

However, it is predicted that teachers' effective communication with the students will reduce their aggression tendencies (Venter, Poggenpoel \& Myburgh, 2005). Similarly, it is stated that physical and general violence perception decreases as the perception of teacher-student relation increases (Ay1k, 2014). Strengthening communication links with students can contribute to the students' attachment to the school. Otherwise, it is inevitable that the students experience conflicts with their friends and teachers. And in this case, problems related to school security start to arise and the student's attachment to the school is negatively affected. Thus, tendency to violence is observed in the students whose attachment to the school is lower (Kermit \& Flanary, 1996), which supports this case.

According to psychological counselors, another factor that affects the school security is school security system. It is necessary to provide a secure education environment for the students, teachers, managers and the personnel to carry on education activities healthfully. Today, technological tools are used to provide physical security of the schools. The most common tools are cameras. Besides the security cameras used to monitor the behaviors of the students for the school security, it is stated that security guards and school personnel can be used (Breunlin, Cimmarusti, Bryant-Edwards \& Hetherington, 2002; Hoang, 2001). It shows consistency with this result that it was determined that as the security and regularity perceptions increase, physical and general violence perception decrease; as the security rate of the school and its environment increases, violent behaviors will decrease (Ay1k, 2014). Knowing the threats and risks in the school's environment is important for the interventions and plans related to school security. School security policy can provide a healthful education environment by reducing the risks to minimum.

In another result of the study, the views of the psychological counselors related to their roles and responsibilities were determined as psychological security, responsibility, legal regulations and professional competence. Especially the problems that the students experience with their friends, being unable to express themselves properly and their aggressive responses can affect the school security negatively. The school counselor can provide psychological support to the students in cases like expressing anger properly, conflict resolution skills and empathic behavior. They can also 
support the students to participate in sportive and artistic activities to change their perceptions about security in a positive way.

Lately, on talking about the duties and tasks of the psychological counseling it is underlined that school-based preventive studies should be done. The term preventive has a close connection with the terms like well-being, subjective well-being, making health better, increasing sufficiency, competence, increasing psychological endurance and flexibility, and positive youth development. These terms are positive and related to healthy human development (Owen, 2011). Supporting the interpersonal relations and providing them to get strengthened (Terzi, 2007) can be shown as an example to these preventive studies. Thus, it is thought that the studies that the psychological counselors will do about these subjects can contribute to the development of the students' psychological security.

In another result of the study, evidence showing that some of the psychological counselors do not have professional knowledge related to the school security was obtained. The psychological counselors working in primary and secondary schools do not consider themselves adequate enough to prevent violence and aggressiveness in the school (Uzbaş, 2009); the rate of those who consider themselves inadequate in preventing aggressiveness and violence is $3 \%$ (Peters, 2004), all of these results of other studies are parallel with the results of this study. This result can be evaluated that psychological counselors are not adequately ready enough for the studies that will be conducted on school security. Moreover, it reveals a fact that the as the knowledge of the psychological counselors are not adequate for school security studies, it should be increased.

As a result of the evidence obtained through the study, it is clear that especially the duties of the psychological counselors should be made more accurate to carry on school-based preventive guidance and psychological counseling studies to maintain school security. Hence, among the decision taken in $19^{\text {th }}$ National Educational Council, there is an advisory jurisdiction that Guidance and Psychological Counseling Services should be reorganized involving the roles and responsibilities of school counselors related to school security. In the current regulation, there is no information about the duties of psychological counselors related to school security. Thus, the duties of the psychological counselors related to school security should be made clear with regulations.

Another result of the study shows that the tasks that the psychological counselors can take in terms of school security are preventive studies and studies towards parents. It can be thought that the preventive studies that can be carried on in the school can provide important advantage to prevent the student behaviors involving aggressiveness, violence and bullying, which can affect the school security negatively. The young who encounter violence frequently especially in the social environment where s/he lives, in his/her parents, social circle, in the school, TV and computer games interiorize violence and consider it as a normal fact, and as a result they approve such behaviors (Örki, 2013). Thus, psychological counselors have important duties for the students to display healthier attitudes instead of violence acts. It can be said that with the trainings in the subjects of conflict resolution, anger management, coping with stress, decision making, goal setting, developing social and communication skills that the school counselor gives to the students, it can contribute a lot. In this context, it can be said that psychological counselors have an important task to create an environment where the students feel comfortable and secure psychologically in the school.

In the studies towards parents, regular informing can be done in the subjects of precautions to take for the students not to have problems on their way home or school, how to keep students away from violence, the rules to be obeyed in the school and the behaviors expected from the student. That it was stated that trainings should be given to the parents in the interventions to prevent violence in the school, (Odac1, 2007) supports the finding of this study. Uzbaş (2009) stated that psychological counselors give parent training and individual psychological counseling service, which shows consistency with the result of this study.

\section{Conclusion}

In this study, the roles and responsibilities of the psychological counselors were tried to be analyzed to maintain school security. It is stated that today school security involves classroom order, bullying, aggressiveness and violence acts. Various violence acts like verbal attack, social exclusion, sexual assault (harassment), gun use and starting a gang are considered within school security. Each group in the school can have a different perspective to solve the security problem in the school. Similarities and differences among these various perspectives can be revealed to take advantage of school's organizational process (Astor et al., 2010).

Maintaining security in the schools is necessary for the students to get educated in a healthy education environment. The pedagogues, researchers, school managers, teachers and psychological counselors have an important role for this. Taking physical precautions in the school and the support from the security forces are not adequate to maintain school security. The precautions to take for a secure school should be school-based.

The views of the psychological counselors should be benefited to carry out school-based preventive studies in terms of 
school security. Therefore, the roles and responsibilities of the psychological counselors about the school security can be made clearer with legal regulations. Each school counselor can create a school psychological security plan to prevent security problems in the schools by considering his/her school's conditions. Similar studies can be done in different cities and the roles and responsibilities of psychological counselors can be determined. The views of the psychological counselors can be asked to determine the rules to be followed in terms of school security.

This study has some limitations. The first one of the limitations is that the study is conducted in qualitative method. Quantitative studies that would analyze the relations between the roles and responsibilities of the psychological counselors about school security can contribute to obtained more integrated results. The second limitation of the study is that the study involves 12 psychological counselors working in different school grades in one city center. Repeating the study with psychological counselors working in different cities will provide to obtain stronger results related to roles and responsibilities related to school security.

\section{References}

Astor, R. A., Guerra, N., \& Acker, R. V. (2010). How can we improve school safety research? Educational Researcher, 39(1), 69-78. http://dx.doi.org/10.3102/0013189X09357619

Ayar, N. (2010). Okul güvenliği sorununa farklı bir yaklaşım: Okul polisi uygulaması. Yayımlanmamış Yüksek Lisans Tezi, Sakarya Üniversitesi, Sosyal Bilimler Enstitüsü, Sakarya.

Ayık, İ. (2014). Ortaokullarda şiddet ve okul iklimi arasındaki ilişki (Konya ili örneği). Yayımlanmamış Yüksek Lisans Tezi, Mevlana Üniversitesi, Sosyal Bilimler Enstitüsü, Konya.

Baginsky, M. (2004). Safegurding children and school. Deakin University Press.

Breunlin, D. C., Cimmarusti, R. A., Bryant-Edwards, T. L., \& Hetherington, J. S. (2002). Conflict resolution training as an alternative to suspension for violent behaviour. Journal of Educational Research, 95(6), 349-358. http://dx.doi.org/10.1080/00220670209596609

Bucher, K. T., \& Manning, M. L. (2005). Creating safe schools clearing house: A Journal of Educational Strategies, Issues and Ideas, 79(1), 55-60. Stable URL: http://www.jstor.org/stable/30182108 .

Buffo, D. M. (2005). An investigation of the perceptions of students, teachers and parents concerning with in the elementary schools of a large suburban school district. Unpublished Doctoral Dissertation, Loyola University, Chicago.

Buluç, B. (2006). Okullarada suç ve şiddet. Şule Erçetin (Der.). Okullarda şiddet ve çocuk suçluluğu eğitim ve şiddet. Ankara: Hegem Yayınları.

Çalıkoğlu, A. (2012). Ortaöğretim öğrencilerinin okul güvenliğine ilişkin görüşleri: Çanakkale il merkezi örneği. Yayımlanmamış Yüksek Lisans Tezi, Çanakkale Onsekiz Mart Üniversitesi, Eğitim Bilimleri Enstitüsü, Çanakkale.

Ekiz, D. (2013). Bilimsel araştırma yöntemleri. Ankara: Anı Yayınları.

Erol, F. (2009). Okulda güvenlik sorununa yol açan etkenlerin belirlenmesi. Milli Eğitim Bakanlığı Eğitimi Araştırma ve Geliştirme Dairesi Başkanlığı, Ankara.

Geyin, Ç. (2007). Genel liselerde okul güvenliği algılarının incelenmesi. Yayımlanmamış Yüksek Lisans Tezi, Marmara Üniversitesi, İstanbul.

Goldstein, S. E., Young, A., \& Boyd, C. (2008). Relational aggression at school: Associations with school safety and social climate. Journal of Youth and Adolesence, 37(6), 641-654. http://dx.doi.org/10.1007/s10964-007-9192-4

Grene, M. (2005). Reducing violence and aggression in schools. Trauma Violence Abuse, 6, 236-253. http://dx.doi.org/10.1177/1524838005277406

Güler, Y. K. (2010). İlköğretim birinci kademe öğrencilerinin okul güvenliğine ilişkin algılarının incelenmesi: Sultanbeyli ilçesi örneği. Yayımlanmamış Yüksek Lisans Tezi, Maltepe Üniversitesi, İstanbul.

Hoang, F. Q. (2001). Addressing school violence. FBI Law Enforcement Bulletin, 70(8), 18-24.

Kermit, B., \& Flanary, R. (1996). Protecting your school and students: The safe schools handbook. Nassp Bulletin, 80(579), 44-48. http://dx.doi.org/10.1177/019263659608057908

Klooster, M. V. (2002). School of safety at an urban high school: An in-depth study of students' and teachers' perception. Unpublished Doctoral Dissertation, Pepperdine University, Malibu.

Kumar, R., O’Malley, P. M., \& Johnston, L. D. (2008). Association between physical environment of secondary schools and student problem behavior. A National Study 2000-2003. Environment and Behavior, 40(4), 455-486. 
http://dx.doi.org/10.1177/0013916506293987

Nair, B. (2014). Ergenlerin saldırganlık davranışlarının bazı değiş̧kenler açısından incelenmesi. Yayımlanmamış Yüksek Lisans Tezi, Cumhuriyet Üniversitesi, Eğitim Bilimleri Enstitüsü, Sivas.

Odacı, H. (2007). Çocuk suçları ve şiddet olayları. (Ed. Adem Solak). Okullarda şiddet ve çocuk suçluluğu. Ankara: Hegem Yayınları.

Örki, H. (2013). Okullarda şiddet ve suç: Eskişehir örneği. Yayımlanmamış Yüksek Lisans Tezi, Anadolu Üniversitesi, Sosyal Bilimler Enstitüsü, Eskişehir.

Osher, D., George, G. B., Jeffrey, R. S., \& Walter, D. (2010). How can we improve school discipline? Educational Researcher, 39(1), 48-58. http://dx.doi.org/10.3102/0013189X09357618

Owen, F. K. (2011). Okul temelli önleyici rehberlik ve psikolojik danışma. Ankara: Anı Yayıncılık.

Özer, N. (2006). İlköğretim ikinci kademe öğrencilerinin okul güvenliğine ilişskin algıları. Yayımlanmamış Yüksek Lisans Tezi, İnönü Üniversitesi, Sosyal Bilimler Enstitüsü, Malatya.

Peters, M. A. (2004). Knowledge and roles in the school violence agenda: A national survey of school psychologists. Unpublished Doctoral Dissertation, State University of New York, New York.

Posluoğlu, F. G. (2014). Eğitim kurumlarında öğretmen ve idarecilerin okul güvenliği ile ilgili algı ve çözüm yollarını belirleyebilmek için çalışma. Yayımlanmamış Yüksek Lisans Tezi, Yeditepe Üniversitesi Sosyal Bilimler Enstitüsü, İstanbul.

Reeves, M. A., Kanan, L. M., \& Plog, A. E. (2010). Comprehensive planning for safe learning environments. New York: Taylor and Francis Group.

Schneider, T., Walker, H., \& Sprague, J. (2000). Safe school design: A handbook for educational leaders- applying the principles of crime prevention through environmental design. Eugene, OR: Clearinghouse on Educational Management, University of Oregon.

Terzi, Ş. (2007). Okullarda yaşanan şiddeti önleyici bir yaklaşım: Kendini toparlama gücü. Aile ve Toplum, 3(12), 73-82.

Uzbaş, A. (2009). Okul psikolojik danışmanlarının okulda saldırganlık ve şiddete yönelik görüşlerinin değerlendirilmesi. Mehmet Akif Ersoy Üniversitesi Ĕ̈itim Fakültesi Dergisi, 9(18), 90-110.

Venter, M., Poggenpoel, M., \& Myburgh, C. P. H. (2005). The phenomenon of aggressive behavior of learners in the school situation. Education, 126(2), 312-315.

Yıldırım, A., \& Şimşek, H. (2006). Sosyal bilimlerde nitel araştırma yöntemleri. Ankara: Seçkin Yayıncılık.

\section{$(\mathrm{Cc}) \mathbf{B Y}$}

This work is licensed under a Creative Commons Attribution 3.0 License. 